InVisible Culture • Issue 33: After Douglas Crimp

\title{
After Douglas Crimp \\ Questionnaire Response: \\ Marc Siegel
}

\section{Marc Siegel}

Published on: Jan 05, 2022

DOI: $10.47761 / 494 a 02 f 6.4 a f 8426 b$

License: Creative Commons Attribution 4.0 International License (CC-BY 4.0). 


\section{Answer Louise Lawler's question in October: "What would Douglas Crimp say?" Or, to follow the title of Lawler's exhibition: Why Pictures Now?}

We could call it, "Why No Pictures Now." Louise Lawler's contribution to the section commemorating Douglas Crimp in October 171 (Winter 2020) is heartwrenchingly brilliant. "What would Douglas Crimp say?" Confronted with the emptiness of his absence, that's the question many of Douglas's friends ask themselves almost every day. Doing so is one way of activating memories and keeping Douglas's perspectives and inquisitive attentiveness alive within us. In this or that enjoyable or difficult situation, confronted with this or that theoretical, political, or amorous conundrum, in the midst of this or that culinary or aesthetic experience, what would Douglas Crimp say? Lawler's question, of course, is posed in a specific context. It appears as title and sole text of her remembrance of her friend in the art journal for which Crimp served in various editorial functions over approximately thirteen years. As editor and author between 1977-1990, Crimp helped shape the journal's development as a crucial organ for debates about modernism and postmodernism. In the late 1980s, he eventually opened up October to contemporary strands of cultural studies, a move rejected by his fellow editors. He edited a special issue on AIDS in 1987 (October 43 "AIDS: Cultural Analysis/Cultural Activism") that was subsequently released in book form and became the journal's best-selling issue. In 1990, in the midst of Crimp's plans to publish an issue of October with texts based on presentations from the pathbreaking conference “How Do I Look? Queer Film and Video," Krauss and Michelson unceremoniously fired him and left him scrambling for a way to make a living. We don't need to speculate about what Crimp would say about October, because he already said it on numerous occasions.

About October 43, he said:

"My fellow editors came, I think, to resent that success, and particularly the fact that for a new group of readers, October was 'Douglas Crimp's magazine' not 'Rosalind Krauss and Annette Michelson's magazine.' Becoming an AIDS activist transformed me intellectually. It transformed what I wanted to work on, and it brought me, methodologically, closer to cultural studies. I was bringing that perspective to bear at a time when Rosalind and Annette had more or less withdrawn from the day-to-day work of the magazine-they had grown tired of it." 1

About publication plans for How Do I Look?, he said:

"That was the precipitating reason that I left. The papers of the conference that my 
reading group organized had been accepted by the editors for an issue of October, but when the texts came in they didn't want to publish them. There were two texts in particular that they rejected. It's a long and complicated story - like any divorce - but I was forced out."를

As a summary of the reasons he got fired, he said:

"The AIDS issue is, in fact, the reason I was pushed out of October. Of course on some level my fellow editors were pleased that October got so much attention. But in the end I think it got too much attention for their taste. You know, my name was suddenly up front. I had been seen by them as the younger one going to the office and doing the day-to-day work on the journal. Even after I became a full editor, I still essentially did the job of managing editor. I did all the proofreading, I did the layout, I did everything. By then it had gotten to the point where the other editors were not as hands-on with the journal as they were when I first got involved with it, so a lot was left to me. So when I said that I wanted to do a special issue on AIDS, they said OK. They never read any of the material before it came out, and I think they probably didn't read it at all until later, after it got so much attention. And then they didn't really like it. For them, it wasn't what October was about. And you can see from what they've done since I left what they think October is about: it's about a retrenchment around a traditional notion of high modernism. In the 1980s, October was thought of as the journal of postmodernism. But the commitments of Krauss and Michelson and the people now connected with the journal have always been much more high modernist in their orientation." $\underline{3}$

Given this history and the ensuing development of both October and Crimp's work over the thirty years since his firing - retrenchment in high modernism without radical interdisciplinarity vs. continued expansion into cultural, queer, film and dance studies what would Douglas Crimp say about October reckoning with his life and work after his death? $\underline{4}$ What would Douglas Crimp say to his friends who contribute to such a section?

Lawler doesn't answer the question, "What would Douglas Crimp say?" She simply poses it, twice, and provides a blank page. No appraisals, no anecdotes, no pictures. October's distinctive page layout, with its bibliographic and copyright notice on the bottom, comes more clearly into focus. Lawler doesn't add a page of memories to the journal's brief compendium. She instead frames the emptiness at the heart of its commemoration with a question, "What would Douglas Crimp say?" 
Marc Siegel is Professor of Film Studies at the Johannes Gutenberg University in Mainz.

Click here to return to the other questionnaire responses.

\section{Footnotes}

1. “Close Encounters: Douglas Crimp with Jarrett Earnest," Brooklyn Rail (October 2016): https://brooklynrail.org/2016/10/art/douglas-crimp-with-jarrett-earnest.

2. Matthias Danbolt, "Front Room - Back Room : An Interview with Douglas Crimp," May 2015 (First published in Trikster - Nordic Queer Journal, \#2, 2008). Available as pdf at http://www.f-r-a-n-k.org/publications/04/04.html. Fortunately, the texts by Richard Fung, Teresa de Lauretis, Stuart Marshall, Judith Mayne, Kobena Mercer, and Cindy Patton were later published in book form by Bay Press, a collection that became a founding contribution to queer film studies. See Bad Object-Choices (eds.), How Do I Look? Queer Film and Video (Seattle: Bay Press, 1991). $ヒ$

3. Danbolt, "Front Room - Back Room."

4. In 2016 Crimp said: "It's a big job to find things you want to publish, especially if your notion of what is right for your journal is as narrow as it always has been for October. It became narrower still after I left. The interdisciplinary aspect that characterized the first ten years largely disappeared. Annette is an intellectual with very broad interests-in music, film, literature, politics, and art-and she gave the magazine a breadth that I don't feel it has anymore, even though she is still there. It's now much more a visual art publication-and a high-modernist one, at that." See “Close Encounters." In 2008 Crimp said: "If you look at October's issue on "Visual Culture" (Summer 1996), there's a real retrenchment with regard to disciplinarity, whereas October had earlier been committed to interdisciplinarity, because of its commitments to poststructuralist theory, but also to not just the visual arts, but also literature, film, and a range of different subjects such as politics and psychoanalysis. But then interdisciplinarity came to seem to them something else, something that threatened their high modernist position." See Danbolt, "Front Room-Back Room." In "Getting the Warhol We Deserve," published in the first issue of InVisible Culture, Crimp carefully articulated the stakes of such disciplinary border policing for cultural studies approaches to queer culture. See "Getting the Warhol We Deserve: Cultural Studies and Queer Culture," In Visible Culture 1 (1998), https://ivc.lib.rochester.edu/getting-the-warhol-we-deserve-cultural-studiesand-queer-culture $/$. 